\title{
Spelling performance of students with and without Attention Deficit Hyperactivity Disorder
}

Clarissa dos Santos Pereira(1) Nelba Maria Teixeira Pisacco ${ }^{(1)}$ Luciana Vellinho Corso(1) Beatriz Vargas Dorneles ${ }^{(1)}$

1) Universidade Federal do Rio Grande do Sul, Porto Alegre, Rio Grande do Sul, Brasil.

Research support source: Attention Deficit Hyperactivity Disorder Program- ProDAH/ Hospital de Clínicas de Porto Alegre; Coordenação de Aperfeiçoamento de Pessoal de Nível Superior- CAPES.

Conflict of interests: Nonexistent

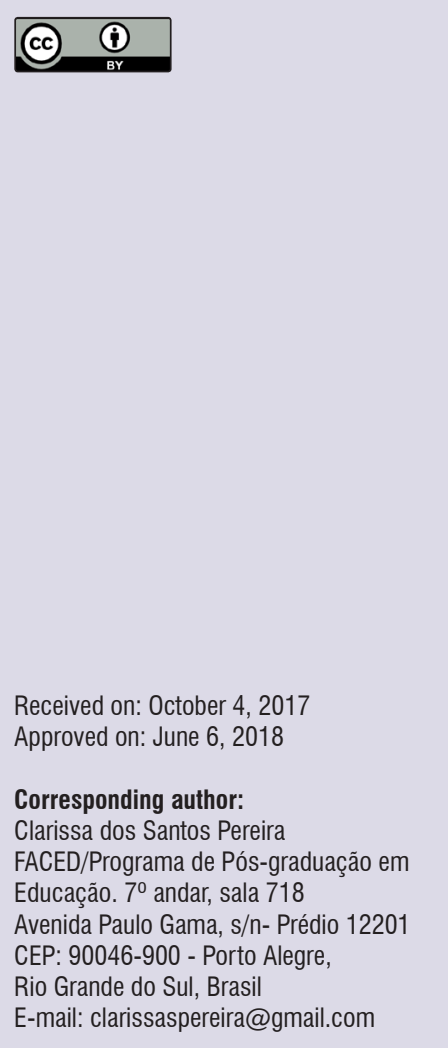

\section{ABSTRACT}

Purpose: to characterize and compare the spelling performance of students with and without Attention Deficit Hyperactivity Disorder.

Methods: sample including 244 Brazilian students from the 3rd to the 5th year, from three public schools (189 without and 55 with the disorder). Students were assessed and classified according to the spelling errors in a word dictation. The average performance was compared per school year, condition (having Attention Deficit Hyperactivity Disorder or not) and interaction between year and condition. The performance was also compared to the results of the study by Moojen (2011), on orthographic performance in Elementary School.

Results: students with Attention Deficit Hyperactivity Disordershowed a higher average in the total number of errors, in the Phoneme/Grapheme Conversion, Simple Contextual Rules and Language Irregularities categories. In the group without Attention Deficit Hyperactivity Disorder, there was a greater reduction of errors among the school grades (3rd, 4th, 5th). In relation to the study by Moojen (2011), students with the disorder had a lower average.

Conclusion: evidence showed that the presence ofAttention Deficit Hyperactivity Disorderinfluenced the spelling performance of the students evaluated.

Keywords: Attention Deficit Disorder with Hyperactivity; Education; Learning; Handwriting 


\section{INTRODUCTION}

Attention Deficit Hyperactivity Disorder (ADHD) is classified as a neurobiological disorder, caused by genetic or environmental factors ${ }^{1}$. A meta-analysis ${ }^{2}$ indicated that the worldwide prevalence of the disorder in children and adolescents is $5.29 \%$. The symptoms that characterize ADHD, inattention, impulsivity or hyperactivity, can impair the social, academic or professional life of children, adolescents or adults diagnosed with the disorder, which causes a frequent search for specialized clinical care ${ }^{3}$ and low school performance $e^{4,5}$.

In comparison with mathematics and reading, research has shown that difficulties in written expression, which involve problems with spelling, the application of spelling rules or textual production, occur more frequently in these students ${ }^{6-8}$. Writing is not simply a transcription of speech, nor an exclusively motor act. There are many cognitive and linguistic components involved in this process. When writing, the sensory, motor, oral language, memory, and attention functional systems are recruited simultaneously, and they work together in this ability ${ }^{9}$. Silva, Cunha and Capellini $(2011)^{10}$ suggest that the phonetic-phonological and grammatical problems in the performance of students with ADHD may be due to factors such as lack of attention and inhibitory control and not specifically to lesser linguistic development.

Unlike what happens in the acquisition of speech in hearing subjects, the learning of the written language does not occur naturally, spontaneously, but systematic teaching is necessary. Thus, in addition to the skills that are recruited for the writing activity, the learning of writing also involves the appropriation of cultural knowledge and linguistic aspects of the alphabetic writing system ${ }^{11}$. This appropriation is directly related to the concept of spelling. Over time, with the widespread use of the alphabet in societies, it was necessary to organize, for the sake of writing, the variation in the different modes of orality of languages. This fact determined the invention of fixed forms by means of orthography $^{12}$. In addition, the ways of writing, the spatial orientation and the segmentation of sentences and words were adjusted over time ${ }^{13}$.

Transparency and orthographic opacity characterize the alphabetical principle of some languages, including the Brazilian Portuguese language. The orthographic transparency is related to regularities, in which each phoneme corresponds to only one grapheme and each grapheme corresponds to only one phoneme. The irregularity, in which there are graphemes that correspond to more than one phoneme and phonemes that correspond to more than one grapheme, characterizes the orthographic opacity of the writing system ${ }^{11}$. Using different classifications, Brazilian studies have shown that the acquisition of writing occurs in an evolutionary path between alphabetic and orthographic principles ${ }^{13-16}$. The alphabetic principles are related to transparency and the orthographic principles to the opacity of the language. Initially, in the alphabetical stage, the phonemic awareness is constructed, which comprises the understanding of the relations between the univocal correspondences between phoneme and grapheme ${ }^{14}$. This stage gains improvements when the writer becomes aware that there is not a single relation for all graphemes and phonemes and apprehends the rules according to the context of the letter in the word (e.g. one $r$ or doubler at the beginning of the word) and irregularities, which need memorization because they are part of the etymological history of the language. Thus, the construction of orthographic skills reflects the hypotheses of the subject's writing, implying errors that are sometimes expected along this path and which tend to be overcome as schooling advances ${ }^{13,14}$.

Moojen (2011) ${ }^{14}$ carried out a survey of elementary and high school students from private and public schools in the city of Porto Alegre and analyzed the students' performance in the development from alphabetical to orthographic writing. The author developed an instrument, called Balanced Dictation, which contains fifty words chosen from the frequency of error types in the Portuguese language, grouping them into four categories: Phoneme/Grapheme Conversion; Simple Contextual Rules; Complex Contextual Rules; Language Irregularities. The author compared the average performance of the school years and the results showed that the difficulties tend to decrease as education advances. Research has shown, however, that this reduction is not always the case for students with ADHD. Studies compared the performance in written expression between students with typical development and students with ADHD. Despite the methodological specificities, the low orthographic performance of students with ADHD was highlighted as a result, as well as a slower overcoming of alphabetical errors or mistakes against the spelling rules s,7,7-23. $^{6}$.

The objective of this study was to characterize and compare the orthographic performance of students with and without Attention Deficit Hyperactivity Disorder. The hypothesis was that the students with ADHD would 
evidence a lower performance in comparison with their peers and with the study by Moojen (2011) ${ }^{14}$.

\section{METHODS}

\section{Ethical considerations}

This study was registered on the Brazil Platform under Certificate of Presentation for Ethical Appreciation 29736714.7.0000.5327 and approved under opinion 660.967 by the Research Ethics Committee at Hospital de Clínicas de Porto Alegre. The responsible caregivers of all participating students granted their authorization by signing the Free and Informed Consent Form.

\section{Participants}

The sample selection stages were held at three public schools of the state network in the city of Porto Alegre. Students $(\mathrm{N}=262)$ whose participation was authorized by means of the Consent Form underwent a clinical evaluation to diagnose ADHD, which was performed by a multidisciplinary team of the Attention Deficit Hyperactivity Disorder Program (PRODAH) of the Hospital de Clínicas de Porto Alegre. For the diagnosis, the Swanson, Nolan, and Pelham (SNAP-IV) ${ }^{24}$ questionnaire was used, completed by the teachers, analysis of neuropsychological tests (Raven's Progressive Colored Matrix Test - Special Scale, applied to students aged 8 to 11 years ${ }^{25}$ and General Scale ${ }^{26}$, for students over 12 years) applied by psychologists. Subsequently, experienced psychiatrists conducted clinical interviews, confirming the diagnosis of ADHD or not. Upon completion of the diagnosis, the Wechsler Intelligence Scale for Children - Vocabulary and Block Design ${ }^{27}$ subtests were applied only to students diagnosed with ADHD and those with an estimated IQ of less than 80 were withdrawn from the study $(n=5)$, in order to prevent intellectual deficits from interfering in the results. As the application of this test should be done individually, it was decided to perform it only in students with a diagnosis of ADHD, as there was little time for the evaluation procedures. In the last stage of student selection, the Balanced Dictation ${ }^{14}$ was corrected, in which participants who were not literate $(n=13)$ were excluded from the survey. Students who used a restricted repertoire of letters in the writing of the applied test were considered illiterate. After the exclusion of illiterate students and students suffering from ADHDwith IQ below 80, the sample consisted of 244 students, who were divided into two groups: with and without ADHD. Table 1 shows the sample description data.

Table 1. Sample description

\begin{tabular}{ccccc}
\hline & & Without ADHD & With ADHD & Total \\
\hline \multirow{4}{*}{ School Year } & 3rd year & 45 & 19 & $64(26.2 \%)$ \\
& 4th year & 75 & 25 & $100(41.0 \%)$ \\
& 5th year & 69 & 11 & $80(32.8 \%)$ \\
& Total & $189(77.5 \%)$ & $55(22.5 \%)$ & 244 \\
\hline \hline \multirow{2}{*}{ Sex } & Male & 102 & 28 & $130(53.3 \%)$ \\
& Female & 87 & 27 & $114(46.7 \%)$ \\
\cline { 2 - 5 } Age & 3rd year & $M=8.61(S D=0.39)$ & $M=8.56(S D=0.36)$ & \\
& 4th year & $M=9.69(S D=0.64)$ & $M=9.88(S D=0.75)$ & \\
& 5th year & $M=10.86(S D=0.68)$ & $M=11.32(S D=1.26)$ & \\
\hline
\end{tabular}

Legend: ADHD- Attention Deficit Hyperactivity Disorder; M (mean); SD (standard deviation). 


\section{Procedures}

The instrument used for data collection was the Balanced Dictation ${ }^{14}$, which contains 50 words that permit the classification of errors by alphabetical/ spelling categories. This dictation was applied in the students' school context, in group. The evaluator explained the activity to the students, following the guidelines of the instrument. The words were pronounced as they are spoken in the region where the instrument was applied and dictated orally and repeated only once. The students wrote the words on plain paper and were instructed not to erase letters or words, but to rewrite them in parentheses if they considered it necessary.

The students' misspellings were counted by number of errors, being that correct answers were worth zero and errors were worth one point. The errors were added up and a classification was made according to the categories (Phoneme/Grapheme Conversion, Simple Contextual Rules, Complex Contextual Rules and Language Irregularities) proposed by Moojen (2011) ${ }^{14}$. In each of these categories, there is a classification by subcategories, which are detailed next:

a) Phoneme/Grapheme Conversion: voiceless/ voiced, random substitution; letter inversion; letter transposition; letter or syllable omission; letter addition.

b) Simple Contextual Rules: r/rr; c/qu/g/gu; e/i - o/u; nasalization; end-of-syllable $\mathrm{m} / \mathrm{n}$.

c) Complex Contextual Rules: proparoxytone (i.e. words that have the accent in the third syllable, counting from the final syllable); paroxytone (i.e. words that have the accent in the second syllable, counting from the final syllable); oxytone (i.e. words that have the accent in the final syllable); accent addition; accent switch.

d) Language Irregularities: final l/u; initial h; j/g; li/lh; $\mathrm{x} / \mathrm{ch}$; $\mathrm{x} /$ sound like $\mathrm{z}$; $\mathrm{x} /$ sound like $\mathrm{s}$; $\mathrm{x}$ / sound like cs; initial c by s; initial s by c; ç; ss; sc; s / sound like $z$.

With the changes in primary education in Brazili ${ }^{28}$, which changed from eight to nine years, changing the age of admission and the distribution of series to school years, it was necessary to establish correspondence between the standardized averages, which had been determined from research with students from grades 3 to 8 . Therefore, in this study, the following correspondences were used: $4^{\text {th }}$ year: $3^{\text {rd }}$ grade; $5^{\text {th }} y e a r:$ $4^{\text {th }}$ grade and the current $3^{\text {rd }}$ year was not compared to the means of the test, as $2^{\text {nd }}$ grade students did not participate in the research used as a reference ${ }^{14}$. The reference means of the test used in this study are the same as those proposed for low middle-class students in public education.

\section{Data analysis}

This is a cross-sectional quantitative study. Two analyses were performed.

1) Comparison between the error means of the groups with and without ADHD based on the classification by subcategories and categories of errors. It was evaluated whether there were school-year effects, that is, reduction or increase of errors from one year to another in each group. The differences in total errors in the three school years, joining all the students with and without ADHD - were also presented, but were not considered in the highlights of the results or discussion, as the objective of this study rests on the interaction effect, that is, interferences of ADHD in the performance of the students. In this same test, we analyzed the significant differences of errors regarding the condition (with/without ADHD) in each school year and in the three years together. After this first set of results, a comparison was made, following the same criteria (year and condition), which evaluated the total errors made in the dictation. The distributions of the variables were verified using the Shapiro-Wilk normality test. In order to compare the effects of condition (with/ without ADHD), school year and interaction (condition and year) of the errors in each category and its subcategories, the Generalized Linear Models analysis was performed. The outcomes considered were counting variables. A Poisson distribution with logarithmic binding function was employed. When significant $(p$ $<0.05)$, the Bonferroni Post-hoc test was used.

2) The error means of the groups with and without $A D H D$, of the $4^{\text {th }}$ and $5^{\text {th }}$ year, were compared with the means of the reference study ${ }^{14}$. The average of each year was calculated for each condition (with/without ADHD). These standardized means were compared using the t-test for a single sample. The reference value used was zero. Significant positive values indicated that the members of the collected sample made more errors. Significant negative values indicated that the members of the sample performed better (lower mean number of errors). The level of significance was set at $5 \%(p<0.05)$.

\section{RESULTS}

Table 2, which describes the results of the Phoneme/Grapheme Conversion category, shows 
that, in the non-ADHD group, the error means between school years was significantly different in letter or syllable omission variables and total errors of the Phoneme/Grapheme Conversiontype, with fewer errors in the more advanced school years. In the group with $A D H D$, the means in these variables were statistically different only between the $3^{\text {rd }}$ and $4^{\text {th }}$ year and between the $3^{\text {rd }}$ and $5^{\text {th }}$ year, being higher in the $3^{\text {rd }}$ year in both cases. In the comparison between the groups, the group with $A D H D$, in the letter or syllable omission variable, showed higher error means in the $3^{\text {rd }}$ and $5^{\text {th }}$ years, identified based on a statistically significant difference. In the total variable of Phoneme/Grapheme Conversionerrors, the differences were significant in the comparison between the two groups (with/without $A D H D)$ in the three years, that is, the students with ADHD had higher error means. This also occurred in the voiceless/voiced, random substitution, letter transposition and letter addition variables in the averages of the three school years grouped in a single set $\left(3^{\text {rd }}\right.$ to $5^{\text {th }}$ year).

Table 2. Group performance in Phoneme/Grapheme Conversion

\begin{tabular}{|c|c|c|c|c|c|c|c|}
\hline & \multirow[b]{2}{*}{ Year } & \multicolumn{2}{|c|}{ Condition } & \multirow[b]{2}{*}{$\begin{array}{l}\text { Total per year } \\
\text { (SE) }\end{array}$} & \multirow[b]{2}{*}{ p1 } & \multirow[b]{2}{*}{ p2 } & \multirow[b]{2}{*}{ p3 } \\
\hline & & $\begin{array}{c}\text { Without ADHD } \\
\text { Mean (SE) }\end{array}$ & $\begin{array}{c}\text { With ADHD } \\
\text { Mean (SE) }\end{array}$ & & & & \\
\hline \multirow{4}{*}{$\begin{array}{l}\text { voiceless/ } \\
\text { voiced }\end{array}$} & $3^{\circ}$ & $1.8(0.20)$ & $3.3(0.42)$ & $2.4 \mathrm{a}(0.20)$ & $<0.001$ & $<0.001$ & 0.858 \\
\hline & $4^{\circ}$ & $1.1(0.12)$ & $2.0(0.28)$ & $1.5 b(0.13)$ & & & \\
\hline & $5^{\circ}$ & $0.6(0.09)$ & $1.3(0.34)$ & $0.9 c(0.13)$ & & & \\
\hline & total three years & $1.1 \mathrm{~A}(0.79)$ & $2.0 \mathrm{~B}(0.22)$ & & & & \\
\hline \multirow{4}{*}{$\begin{array}{l}\text { random } \\
\text { substitution }\end{array}$} & $3^{\circ}$ & $2.2(0.22)$ & $3.6(0.44)$ & $2.8 \mathrm{a}(0.22)$ & $<0.001$ & $<0.001$ & 0.203 \\
\hline & $4^{\circ}$ & $1.1(0.12)$ & $1.8(0.27)$ & $1.4 b(0.13)$ & & & \\
\hline & $5^{\circ}$ & $0.4(0.08)$ & $1.2(0.33)$ & $0.7 c(0.11)$ & & & \\
\hline & total three years & $0.94 \mathrm{~A}(0.08)$ & $2.0 \mathrm{~B}(0.22)$ & & & & \\
\hline \multirow{4}{*}{$\begin{array}{c}\text { letter } \\
\text { transposition }\end{array}$} & $3^{\circ}$ & $0.3(0.08)$ & $0.4(0.15)$ & $0.4(0.08)$ & 0.123 & $<0.001$ & 0.111 \\
\hline & $4^{\circ}$ & $0.4(0.15)$ & $0.4(0.13)$ & $0.2(0.05)$ & & & \\
\hline & $5^{\circ}$ & $0.1(0.03)$ & $0.5(0.20)$ & $0.2(0.06)$ & & & \\
\hline & total three years & $0.1 A(0.29)$ & $0.4 \mathrm{~B}(0.92)$ & & & & \\
\hline \multirow{4}{*}{$\begin{array}{c}\text { letter or } \\
\text { syllable } \\
\text { omission }\end{array}$} & $3^{\circ}$ & $2.4 \mathrm{aA}(0.23)$ & $6.4 \mathrm{aB}(0.58)$ & $3.9(0.26)$ & $<0.001$ & $<0.001$ & $<0.001$ \\
\hline & $4^{\circ}$ & $1.7 \mathrm{bA}(0.15)$ & $1.9 \mathrm{bA}(0.28)$ & $1.8(0.15)$ & & & \\
\hline & $5^{\circ}$ & $0.9 \mathrm{cA}(0.12)$ & $3.0 \mathrm{bB}(0.52)$ & $1.7(0.18)$ & & & \\
\hline & total three years & $1.6(0.10)$ & $3.3(0.27)$ & & & & \\
\hline \multirow{4}{*}{ letter addition } & $3^{\circ}$ & $0.5(0.11)$ & $1.0(0.23)$ & $0.7 a(0.11)$ & 0.001 & 0.001 & 0.378 \\
\hline & $4^{\circ}$ & $0.2(0.06)$ & $0.3(0.11)$ & $0.3 b(0.06)$ & & & \\
\hline & $5^{\circ}$ & $0.3(0.06)$ & $0.8(0.27)$ & $0.5 \mathrm{ab}(0.09)$ & & & \\
\hline & total three years & $0.3 A(0.04)$ & $0.6 \mathrm{~B}(0.11)$ & & & & \\
\hline \multirow{4}{*}{$\begin{array}{l}\text { totalPGC } \\
\text { errors }\end{array}$} & $3^{\circ}$ & $7.2 \mathrm{aA}(0.4)$ & $15.7 a B(0.91)$ & $10.6(9.79)$ & $<0.001$ & $<0.001$ & $<0.001$ \\
\hline & $4^{\circ}$ & $4.2 \mathrm{bA}(0.24)$ & $6.4 \mathrm{bB}(0.51)$ & $5.2(4.68)$ & & & \\
\hline & $5^{\circ}$ & $2.3 \mathrm{cA}(0.18)$ & $6.7 \mathrm{bB}(0.78)$ & $3.9(3.41)$ & & & \\
\hline & total three years & $4.1(3.81)$ & $8.8(7.91)$ & & & & \\
\hline
\end{tabular}

Legend: Analysis of Generalized Linear Models.Poisson distribution with logarithmic binding function.Bonferroni's post-hoc test. SE - Standard error; p1- $\mathrm{p}$-value of the year; p2-p-value of condition (with/without ADHD); p3- $p$-value of interaction (year*condition). Significant values $(p<0.05)$ are highlighted. When an interaction effect exists, only p3 stands out. Small letters compare the school years in each group individually, with a drop or not in errors from one year to the other; capital letterscompare conditions (with/without ADHD) in each school year, with performance differences between the groups. ADHD- Attention Deficit Hyperactivity Disorder; PGC - Phoneme/Grapheme Conversion. 
Table 3 presents the results of the Simple Contextual Rulescategory. In the total error variable in Simple Contextual Rules, there was a significant difference in the group without ADHD between the three years analyzed, which characterizes a reduction of errors as schooling advances. This did not occur in the group with ADHD in any of the variables. In the intergroup comparison (with/without $A D H D$ ) of each school year, the error means were significantly different in the variables $\mathrm{e} / \mathrm{i}-\mathrm{o} / \mathrm{u}$ (in the $4^{\text {th }}$ and $5^{\text {th }}$ year), end-ofsyllable $\mathrm{m} / \mathrm{n}$ (in the three years) and total errors in Simple Contextual Rules (in the three years), representing better performance in some group. In these three cases, it was in the group without ADHD.

Table 3. Group performance in Simple Contextual Rulescategory

\begin{tabular}{|c|c|c|c|c|c|c|c|}
\hline & \multirow[b]{2}{*}{ Year } & \multicolumn{2}{|c|}{ Condition } & \multirow[b]{2}{*}{$\begin{array}{l}\text { Total per year } \\
\text { (SE) }\end{array}$} & \multirow[b]{2}{*}{ p1 } & \multirow[b]{2}{*}{ p2 } & \multirow[b]{2}{*}{ p3 } \\
\hline & & $\begin{array}{c}\text { Without ADHD } \\
\text { Mean (SE) }\end{array}$ & $\begin{array}{c}\text { With ADHD } \\
\text { Mean (SE) }\end{array}$ & & & & \\
\hline \multirow{4}{*}{$r / r r$} & $3^{\circ}$ & $1.9(0.2)$ & $2.8(0.4)$ & $2.3 a(0.2)$ & $<0.001$ & $<0.001$ & 0.421 \\
\hline & $4^{\circ}$ & $0.9(0.1)$ & $1.4(0.2)$ & $1.1 b(0.1)$ & & & \\
\hline & $5^{\circ}$ & $0.5(0.1)$ & $1.2(0.3)$ & $0.8 \mathrm{~b}(0.1)$ & & & \\
\hline & total three years & $0.9 A(0.1)$ & $1.7 \mathrm{~B}(0.2)$ & & & & \\
\hline \multirow{4}{*}{$c / q u-g / g u$} & $3^{\circ}$ & $0.4(0.1)$ & $0.5(0.2)$ & $0.5(0.1)$ & 0.172 & 0.087 & 0.710 \\
\hline & $4^{\circ}$ & $0.3(0.1)$ & $0.5(0.1)$ & $0.4(0.1)$ & & & \\
\hline & $5^{\circ}$ & $0.2(0.1)$ & $0.4(0.2)$ & $0.3(0.1)$ & & & \\
\hline & total three years & $0.3(0.0)$ & $0.5(0.1)$ & & & & \\
\hline \multirow{4}{*}{$e / i-0 / u$} & $3^{\circ}$ & $3.0 \mathrm{aA}(0.3)$ & $3.4 \mathrm{aA}(0.4)$ & $3.2(0.2)$ & $<0.001$ & $<0.001$ & 0.006 \\
\hline & $4^{\circ}$ & $1.3 \mathrm{bA}(0.1)$ & $2.1 \mathrm{bB}(0.3)$ & $1.6(0.1)$ & & & \\
\hline & $5^{\circ}$ & $0.9 \mathrm{bA}(0.1)$ & $2.5 \mathrm{abB}(0.5)$ & $1.5(0.2)$ & & & \\
\hline & total three years & $1.5(0.1)$ & $2.6(0.2)$ & & & & \\
\hline \multirow{4}{*}{ nasalization } & $3^{\circ}$ & $1.9(0.2)$ & $3.2(0.4)$ & $2.4 a(0.2)$ & $<0.001$ & $<0.001$ & 0.903 \\
\hline & $4^{\circ}$ & $1.3(0.1)$ & $2.2(0.3)$ & $1.7 b(0.1)$ & & & \\
\hline & $5^{\circ}$ & $0.7(0.1)$ & $1.4(0.4)$ & $1.0 \mathrm{c}(0.1)$ & & & \\
\hline & total three years & $1.2 A(0.1)$ & $2.1 \mathrm{~B}(0.2)$ & & & & \\
\hline \multirow{4}{*}{$\begin{array}{l}\text { end-of-syllable } \\
\mathrm{m} / \mathrm{n}\end{array}$} & $3^{\circ}$ & $1.7 \mathrm{aA}(0.2)$ & $1.0 \mathrm{aB}(0.2)$ & $1.3(0.2)$ & 0.013 & $<0.001$ & $<0.001$ \\
\hline & $4^{\circ}$ & $0.5 \mathrm{bA}(0.1)$ & $1.6 \mathrm{aB}(0.2)$ & $0.9(0.1)$ & & & \\
\hline & $5^{\circ}$ & $0.4 \mathrm{bA}(0.1)$ & $1.3 \mathrm{aB}(0.3)$ & $0.7(0.1)$ & & & \\
\hline & total three years & $0.7(0.1)$ & $1.3(0.2)$ & & & & \\
\hline \multirow{4}{*}{$\begin{array}{l}\text { total SCR } \\
\text { errors }\end{array}$} & $3^{\circ}$ & $8.7 \mathrm{aA}(0.4)$ & $11.0 \mathrm{aB}(0.8)$ & $9.7(0.4)$ & $<0.001$ & $<0.001$ & $<0.001$ \\
\hline & $4^{\circ}$ & $4.3 \mathrm{bA}(0.2)$ & $7.8 \mathrm{bB}(0.6)$ & $5.8(0.3)$ & & & \\
\hline & $5^{\circ}$ & $2.8 \mathrm{cA}(0.2)$ & $6.7 \mathrm{bB}(0.8)$ & $4.3(0.3)$ & & & \\
\hline & total three years & $4.7(0.2)$ & $8.3(0.4)$ & & & & \\
\hline
\end{tabular}

Legend: Analysis of Generalized Linear Models. Poisson distribution with logarithmic bindingfunction.Bonferroni's post-hoc test. SE - Standard error; p1- $p$-value of the year; $p 2-p$-value of condition (with/without ADHD); $p 3$ - $p$-value of interaction (year*condition). Significant values $(p<0.05)$ are highlighted. When an interaction effect exists, only p3 stands out. Small letters compare the school years in each group individually, with a drop or not in errors from one year to the other; capital letterscompare conditions (with/without ADHD) in each school year, with performance differences between the groups. ADHD - Attention Deficit Hyperactivity Disorder; SCR

- Simple Contextual Rules. 
Table 4 presents the results of the category Complex Contextual Rules. Aninteraction effect (year * condition) was found in the variable accent switch. In the group with $A D H D$, the significant difference is between the $4^{\text {th }}$ and $5^{\text {th }}$ year, as the error mean is higher in the $5^{\text {th }}$ year. There was also a condition effect (with/without ADHD) on the same variable, accent switch. In the $4^{\text {th }}$ year, the group with ADHD had a lower mean number of errors and, in the $5^{\text {th }}$ year, the group without ADHD showed a lower mean of errors. When joining the three years, the group with ADHD presented a higher error mean in the proparoxytoneand total errors in Complex Contextual Rules.

Table 4. Group performance in Complex Contextual Rulescategory

\begin{tabular}{|c|c|c|c|c|c|c|c|}
\hline & \multirow[b]{2}{*}{ Year } & \multicolumn{2}{|c|}{ Condition } & \multirow[b]{2}{*}{$\begin{array}{l}\text { Total per year } \\
\text { (SE) }\end{array}$} & \multirow[b]{2}{*}{ p1 } & \multirow[b]{2}{*}{ p2 } & \multirow[b]{2}{*}{ p3 } \\
\hline & & $\begin{array}{c}\text { Without ADHD } \\
\text { Mean (SE) }\end{array}$ & $\begin{array}{l}\text { With ADHD } \\
\text { Mean (SE) }\end{array}$ & & & & \\
\hline \multirow{4}{*}{ proparoxytone } & $3^{\circ}$ & $1.5(0.2)$ & $1.8(0.3)$ & $1.7(0.2)$ & 0.246 & 0.023 & 0.822 \\
\hline & $4^{\circ}$ & $1.4(0.1)$ & $1.8(0.3)$ & $1.6(0.1)$ & & & \\
\hline & $5^{\circ}$ & $1.0(0.1)$ & $1.5(0.4)$ & $1.3(0.2)$ & & & \\
\hline & total three years & $1.3 A(0.1)$ & $1.7 \mathrm{~B}(0.2)$ & & & & \\
\hline \multirow{4}{*}{ paroxytone } & $3^{\circ}$ & $4.2(0.3)$ & $4.4(0.5)$ & $4.3 \mathrm{a}(0.3)$ & 0.010 & 0.303 & 0.313 \\
\hline & $4^{\circ}$ & $3.7(0.2)$ & $4.7(0.4)$ & $4.2 \mathrm{a}(0.2)$ & & & \\
\hline & $5^{\circ}$ & $3.1(0.2)$ & $3.1(0.5)$ & $3.1 \mathrm{~b}(0.3)$ & & & \\
\hline & total three years & $3.7(0.1)$ & $4.0(0.3)$ & & & & \\
\hline \multirow{4}{*}{ oxytone } & $3^{\circ}$ & $1.2(0.2)$ & $1.3(0.3)$ & $1.3 a(0.2)$ & 0.026 & 0.120 & 0.633 \\
\hline & $4^{\circ}$ & $0.9(0.1)$ & $1.3(0.2)$ & $1.1 \mathrm{ab}(0.1)$ & & & \\
\hline & $5^{\circ}$ & $0.6(0.1)$ & $0.8(0.3)$ & $0.7 \mathrm{~b}(0.1)$ & & & \\
\hline & total three years & $0.9(0.1)$ & $1.1(0.2)$ & & & & \\
\hline \multirow{4}{*}{ accent addition } & $3^{\circ}$ & $0.3(0.1)$ & $0.2(0.1)$ & $0.2 a(0.1)$ & $<0.001$ & 0.958 & 0.160 \\
\hline & $4^{\circ}$ & $0.5(0.1)$ & $0.4(0.1)$ & $0.4 \mathrm{a}(0.1)$ & & & \\
\hline & $5^{\circ}$ & $0.7(0.1)$ & $1.3(0.3)$ & $1.0 \mathrm{~b}(0.1)$ & & & \\
\hline & total three years & $0.5(0.1)$ & $0.5(0.1)$ & & & & \\
\hline \multirow{4}{*}{ accent switch } & $3^{\circ}$ & $0.3 \mathrm{aA}(0.1)$ & $0.2 \mathrm{abA}(0.1)$ & $0.2(0.1)$ & 0.269 & 0.923 & 0.001 \\
\hline & $4^{\circ}$ & $0.2 \mathrm{aA}(0.1)$ & $0.04 \mathrm{aB}(0.04)$ & $0.1(0.1)$ & & & \\
\hline & $5^{\circ}$ & $0.1 \mathrm{aA}(0.04)$ & $0.6 \mathrm{bB}(0.2)$ & $0.2(0.1)$ & & & \\
\hline & total three years & $0.2(0.03)$ & $0.2(0.1)$ & & & & \\
\hline \multirow{4}{*}{$\begin{array}{l}\text { total CCR } \\
\text { errors }\end{array}$} & $3^{\circ}$ & $7.6(0.4)$ & $8.0(0.6)$ & $7.8(0.4)$ & 0.074 & 0.006 & 0.393 \\
\hline & $4^{\circ}$ & $6.7(0.3)$ & $8.0(0.6)$ & $7.3(0.3)$ & & & \\
\hline & $5^{\circ}$ & $5.7(0.3)$ & $7.4(0.8)$ & $6.5(0.4)$ & & & \\
\hline & total three years & $6.6 \mathrm{~A}(0.2)$ & $7.8 \mathrm{~B}(0.4)$ & & & & \\
\hline
\end{tabular}

Legend: Analysis of Generalized Linear Models. Poisson distribution with logarithmic bindingfunction.Bonferroni's post-hoc test. SE - Standard error; p1- p-value of the year; $p 2$ - $p$-value of condition (with/without ADHD); $p 3-p$-value of interaction (year*condition). Significant values $(p<0.05)$ are highlighted. When an interaction effect exists, only p3 stands out. Small letters compare the school years in each group individually, with a drop or not in errors from one year to the other; capital letterscompare conditions (with/without ADHD) in each school year, with performance differences between the groups. ADHD - Attention Deficit Hyperactivity Disorder; CCR - Complex Contextual Rules. 
Table 5 shows the results of the Language Irregularities category. As for the school years, in the group without ADHD, there was a significant difference among the three years analyzed in the initial $c$ by $s$ variable and in the total of errors in Language Irregularities, that is, the error mean decreased. In the group with ADHD, this did not occur in any of the variables. In the intergroup comparison (with/without $A D H D$ ), a significant difference was found, representing that the group without ADHD presented a lower error mean than the group with ADHD in the variables final $\mathrm{l} / \mathrm{u}\left(5^{\text {th }}\right.$ year), total errors in Language Irregularities (in the three years). When the three years analyzed were joined in a single group, the group without ADHD also evidenced a (significant) better performance in the variables total li/lh, total $\mathrm{x} / \mathrm{s}$, total $\mathrm{s} / \mathrm{c}$, total $\mathrm{sc}$ and total $\mathrm{s} / \mathrm{z}$.

The total error values were also analyzed by school year and by condition. In the group with ADHD, the mean of the $3^{\text {rd }}$ year was 57.9 (SE $=1.7$ ), against 40.6 $(\mathrm{SE}=1.3)$ in the $4^{\text {th }}$ year and $36.0(\mathrm{SE}=1.8)$ in the fifth. In the non-ADHD group, the mean number of errors in the $3^{\text {rd }}$ year was $43.1(\mathrm{SE}=1.0$ ), against $28.0(\mathrm{SE}=0.6$ ) in the $4^{\text {th }}$ year and $19.1(\mathrm{SE}=0.5)$ in the $5^{\text {th }}$. There was interaction effect $(p<0.001)$. Regarding the condition (with/without ADHD), in the three years analyzed, there was a significant difference, in which the group with ADHD had a higher error mean compared to the group without ADHD. As for the school-year effect, there was a significant difference in the group without ADHD among the three years analyzed, showing a smaller number of errors between one year and another. In the group with $A D H D$, the difference was only significant between the $3^{\text {rd }}$ and $4 \mathrm{t}^{\text {th }}$ year and the $3^{\text {rd }}$ and $5^{\text {th }}$ year, that is, as from the $4^{\text {th }}$ year there was no reduction of errors.

\section{INSERT TABLE 5}

Table 6 presents the results of the comparison of means in each group (with and without ADHD, $4^{\text {th }}$ and $5^{\text {th }}$ year) with the standardization of the Balanced Dictation $^{14}$. The categories and total errors in the dictation were analyzed. For the ADHD group, all means of the standardized variables for the two school years were higher than the reference values. In the group without $A D H D$, in the $4^{\text {th }}$ year, the students presented a lower error mean than the standardized means in the categories Simple Contextual Rulesand Language Irregularities. The same happened in the variable Language Irregularities in the $5^{\text {th }}$ year.

Table 5. Group performance in the category Language Irregularities

\begin{tabular}{|c|c|c|c|c|c|c|c|}
\hline & \multirow[b]{2}{*}{ Year } & \multicolumn{2}{|c|}{ Condition } & \multirow[b]{2}{*}{$\begin{array}{l}\text { Total per year } \\
\text { (SE) }\end{array}$} & \multirow[b]{2}{*}{ p1 } & \multirow[b]{2}{*}{ p2 } & \multirow[b]{2}{*}{ p3 } \\
\hline & & $\begin{array}{c}\text { Without ADHD } \\
\text { Mean (SE) }\end{array}$ & $\begin{array}{l}\text { With ADHD } \\
\text { Mean (SE) }\end{array}$ & & & & \\
\hline \multirow{4}{*}{ final l/u } & $3^{\circ}$ & $0.8 \mathrm{aA}(0.1)$ & $0.8 \mathrm{aA}(0.2)$ & $0.8(0.1)$ & 0.138 & 0.022 & 0.028 \\
\hline & $4^{\circ}$ & $0.6 \mathrm{aA}(0.1)$ & $0.6 \mathrm{aA}(0.2)$ & $0.6(0.1)$ & & & \\
\hline & $5^{\circ}$ & $0.3 \mathrm{bA}(0.1)$ & $0.9 \mathrm{aB}(0.3)$ & $0.5(0.1)$ & & & \\
\hline & total three years & $0.5(0.1)$ & $0.8(0.1)$ & & & & \\
\hline \multirow{4}{*}{ initial h } & $3^{\circ}$ & $1.6(0.2)$ & $1.6(0.3)$ & $1.6 \mathrm{a}(0.2)$ & $<0.001$ & 0.177 & 0.588 \\
\hline & $4^{\circ}$ & $0.9(0.1)$ & $1.3(0.2)$ & $1.1 \mathrm{a}(0.1)$ & & & \\
\hline & $5^{\circ}$ & $0.5(0.1)$ & $0.7(0.3)$ & $0.6 \mathrm{~b}(0.1)$ & & & \\
\hline & total three years & $0.9(0.1)$ & $1.6(0.2)$ & & & & \\
\hline \multirow{4}{*}{$\mathrm{j} / \mathrm{g}$} & $3^{\circ}$ & $0.9(0.1)$ & $1.0(0.2)$ & $1.0 \mathrm{a}(0.1)$ & 0.028 & 0.554 & 0.860 \\
\hline & $4^{\circ}$ & $0.7(0.1)$ & $0.7(0.2)$ & $0.7 a b(0.1)$ & & & \\
\hline & $5^{\circ}$ & $0.4(0.1)$ & $0.5(0.2)$ & $0.5 b(0.1)$ & & & \\
\hline & total three years & $0.7(0.1)$ & $0.7(0.1)$ & & & & \\
\hline \multirow{4}{*}{$\mathrm{li} / \mathrm{lh}$} & $3^{\circ}$ & $0.1(0.1)$ & $0.4(0.1)$ & $0.2(0.1)$ & 0.180 & 0.012 & 0.607 \\
\hline & $4^{\circ}$ & $0.1(0.0)$ & $0.2(0.1)$ & $0.2(0.0)$ & & & \\
\hline & $5^{\circ}$ & $0.0(0.0)$ & $0.2(0.1)$ & $0.1(0.0)$ & & & \\
\hline & total three years & $0.1 A(0.0)$ & $0.3 \mathrm{~B}(0.1)$ & & & & \\
\hline \multirow{4}{*}{$\mathrm{x} / \mathrm{ch}$} & $3^{\circ}$ & $1.3(0.2)$ & $1.4(0.3)$ & $1.3 a(0.2)$ & 0.003 & 0.051 & 0.315 \\
\hline & $4^{\circ}$ & $0.7(0.1)$ & $1.2(0.2)$ & $0.9 \mathrm{~b}(0.1)$ & & & \\
\hline & $5^{\circ}$ & $0.6(0.1)$ & $0.8(0.3)$ & $0.7 b(0.1)$ & & & \\
\hline & total three years & $0.8(0.1)$ & $1.1(0.2)$ & & & & \\
\hline
\end{tabular}




\begin{tabular}{|c|c|c|c|c|c|c|c|}
\hline & \multirow[b]{2}{*}{ Year } & \multicolumn{2}{|c|}{ Condition } & \multirow[b]{2}{*}{$\begin{array}{l}\text { Total per year } \\
\text { (SE) }\end{array}$} & \multirow[b]{2}{*}{ p1 } & \multirow[b]{2}{*}{ p2 } & \multirow[b]{2}{*}{ p3 } \\
\hline & & $\begin{array}{c}\text { Without ADHD } \\
\text { Mean (SE) }\end{array}$ & $\begin{array}{l}\text { With ADHD } \\
\text { Mean (SE) }\end{array}$ & & & & \\
\hline \multirow{4}{*}{$\begin{array}{l}x / \text { sounds } \\
\text { like } z\end{array}$} & $3^{\circ}$ & $2.2(0.2)$ & $1.3(0.3)$ & $1.7 \mathrm{a}(0.2)$ & $<0.001$ & 0.151 & 0.156 \\
\hline & $4^{\circ}$ & $1.4(0.1)$ & $0.8(0.2)$ & $1.0 \mathrm{~b}(0.1)$ & & & \\
\hline & $5^{\circ}$ & $0.5(0.1)$ & $0.7(0.3)$ & $0.6 \mathrm{~b}(0.1)$ & & & \\
\hline & total three years & $1.2(0.1)$ & $0.9(0.1)$ & & & & \\
\hline \multirow{4}{*}{$\mathrm{X} /$ sounds likes } & $3^{\circ}$ & $2.0(0.2)$ & $4.1(0.5)$ & $2.9 \mathrm{a}(0.2)$ & $<0.001$ & $<0.001$ & 0.533 \\
\hline & $4^{\circ}$ & $1.6(0.1)$ & $3.1(0.4)$ & $2.2 \mathrm{a}(0.2)$ & & & \\
\hline & $5^{\circ}$ & $0.9(0.1)$ & $2.4(0.5)$ & $1.4 \mathrm{~b}(0.2)$ & & & \\
\hline & total three years & $1.4 A(0.1)$ & $3.1 \mathrm{~B}(0.3)$ & & & & \\
\hline \multirow{4}{*}{$\begin{array}{l}x / \text { sounds } \\
\text { likecs }\end{array}$} & $3^{\circ}$ & $1.2(0.2)$ & $1.3(0.3)$ & $1.3 a(0.2)$ & $<0.001$ & 0.274 & 0.742 \\
\hline & $4^{\circ}$ & $0.7(0.1)$ & $1.0(0.2)$ & $0.9 \mathrm{a}(0.1)$ & & & \\
\hline & $5^{\circ}$ & $0.4(0.1)$ & $0.5(0.2)$ & $0.4 b(0.1)$ & & & \\
\hline & total three years & $0.7(0.1)$ & $0.9(0.2)$ & & & & \\
\hline \multirow{4}{*}{ initial c by s } & $3^{\circ}$ & $1.3 \mathrm{aA}(0.2)$ & $1.2 \mathrm{aA}(0.3)$ & $1.3(0.2)$ & 0.008 & 0.001 & 0.023 \\
\hline & $4^{\circ}$ & $0.7 \mathrm{bA}(0.1)$ & $1.4 \mathrm{aB}(0.2)$ & $1.0(0.1)$ & & & \\
\hline & $5^{\circ}$ & $0.4 \mathrm{cA}(0.1)$ & $1.0 \mathrm{aA}(0.3)$ & $0.6(0.1)$ & & & \\
\hline & total three years & $0.7(0.1)$ & $1.2(0.2)$ & & & & \\
\hline \multirow{4}{*}{ Ç } & $3^{\circ}$ & $1.7 \mathrm{aA}(0.2)$ & $2.4 \mathrm{aA}(0.4)$ & $2.0(0.2)$ & $<0.001$ & $<0.001$ & 0.048 \\
\hline & $4^{\circ}$ & $1.1 \mathrm{aA}(0.1)$ & $1.5 \mathrm{aA}(0.2)$ & $1.3(0.1)$ & & & \\
\hline & $5^{\circ}$ & $0.6 \mathrm{bA}(0.1)$ & $1.6 \mathrm{aB}(0.4)$ & $1.0(0.1)$ & & & \\
\hline & total three years & $1.0(0.1)$ & $1.8(0.2)$ & & & & \\
\hline \multirow{4}{*}{ initial s by $c$} & $3^{\circ}$ & $0.53(0.11)$ & $0.53(0.17)$ & $0.53(0.10)$ & 0.870 & 0.243 & 0.140 \\
\hline & $4^{\circ}$ & $0.57(0.09)$ & $0.52(0.14)$ & $0.54(0.09)$ & & & \\
\hline & $5^{\circ}$ & $0.40(0.08)$ & $0.91(0.29)$ & $0.60(0.11)$ & & & \\
\hline & total three years & $0.49(0.05)$ & $0.63(0.11)$ & & & & \\
\hline \multirow{4}{*}{ Ss } & $3^{\circ}$ & $2.0(0.2)$ & $2.7(0.4)$ & $2.3 \mathrm{a}(0.2)$ & $<0.001$ & $<0.001$ & 0.720 \\
\hline & $4^{\circ}$ & $1.3(0.1)$ & $2.2(0.3)$ & $1.7 \mathrm{~b}(0.1)$ & & & \\
\hline & $5^{\circ}$ & $1.0(0.1)$ & $1.6(0.4)$ & $1.3 b(0.2)$ & & & \\
\hline & total three years & $1.3 A(0.1)$ & 2.1B $(0.2)$ & & & & \\
\hline \multirow{4}{*}{ Sc } & $3^{\circ}$ & $2.4(0.2)$ & $2.6(0.4)$ & $2.5 a(0.2)$ & $<0.001$ & $<0.001$ & 0.104 \\
\hline & $4^{\circ}$ & $1.4(0.1)$ & $2.2(0.3)$ & $1.8 \mathrm{~b}(0.1)$ & & & \\
\hline & $5^{\circ}$ & $1.0(0.1)$ & $1.9(0.4)$ & $1.4 b(0.2)$ & & & \\
\hline & total three years & $1.5 A(0.1)$ & $2.2 \mathrm{~A}(0.2)$ & & & & \\
\hline \multirow{4}{*}{$\begin{array}{l}\text { s/ sounds } \\
\text { like z }\end{array}$} & $3^{\circ}$ & $1.7(0.2)$ & $2.1(0.3)$ & $1.8 \mathrm{a}(0.2)$ & 0.004 & 0.005 & 0.616 \\
\hline & $4^{\circ}$ & $1.1(0.1)$ & $1.6(0.2)$ & $1.3 \mathrm{~b}(0.1)$ & & & \\
\hline & $5^{\circ}$ & $0.8(0.1)$ & $1.5(0.4)$ & $1.1 \mathrm{~b}(0.2)$ & & & \\
\hline & total three years & $1.2 A(0.1)$ & $1.7 \mathrm{~A}(0.2)$ & & & & \\
\hline \multirow{4}{*}{ Total LI errors } & $3^{\circ}$ & 19.6aA (0.7) & 23.3aB (1.1) & $21.4(0.6)$ & $<0.001$ & $<0.001$ & $<0.001$ \\
\hline & $4^{\circ}$ & $12.9 \mathrm{bA}(0.4)$ & $18.4 \mathrm{bB}(0.6)$ & $15.4(0.4)$ & & & \\
\hline & $5^{\circ}$ & $8.2 \mathrm{CA}(0.3)$ & $15.3 \mathrm{bB}(1.2)$ & $11.2(0.5)$ & & & \\
\hline & total three years & $12.8(0.3)$ & $18.7(0.6)$ & & & & \\
\hline
\end{tabular}

Legend: Analysis of Generalized Linear Models. Poisson distribution with logarithmic bindingfunction.Bonferroni's post-hoc test. SE - Standard error; $p 1$ - $p$-value of the year; p2- $p$-value of condition (with/without ADHD); p3- $p$-value of interaction (year*condition). Significant values $(p<0.05)$ are highlighted. When an interaction effect exists, only p3 stands out. Small letters compare the school years in each group individually, with a drop or not in errors from one year to the other; capital letterscompare conditions (with/without ADHD) in each school year, with performance differences between the groups. ADHD - Attention Deficit Hyperactivity Disorder; LI

- Language Irregularities. 
Table 6. Comparison of performance with reference research ${ }^{14}$

\begin{tabular}{|c|c|c|c|}
\hline \multirow[b]{2}{*}{ Year } & & \multicolumn{2}{|c|}{ Condition } \\
\hline & & Without ADHD & With ADHD \\
\hline \multirow{6}{*}{ 4th year } & & & \\
\hline & Phoneme/Grapheme Conversion & $0.23(1.17)$ & $0.77(1.39)^{*}$ \\
\hline & Simple Contextual Rules & $-0.22(0.81)^{*}$ & $0.46(0.99)^{*}$ \\
\hline & Complex contextual Rules & $-0.23(1.03)$ & $0.35(0.84)^{*}$ \\
\hline & Language Irregularities & $-0.27(1.07)^{\star}$ & $0.50(0.95)^{*}$ \\
\hline & Total BD errors & $-0.18(1.05)$ & $0.63(0.95)^{*}$ \\
\hline \multirow{5}{*}{ 5th year } & Phoneme/Grapheme Conversion & $0.08(0.88)$ & $1.79(1.65)^{*}$ \\
\hline & Simple Contextual Rules & $-0.06(0.63)$ & $0.90(0.88)^{*}$ \\
\hline & Complex contextual Rules & $-0.01(0.86)$ & $0.55(0.61)^{*}$ \\
\hline & Language Irregularities & $-0.22(0.86)^{\star}$ & $0.76(1.13)^{*}$ \\
\hline & Total BD errors & $-0.11(0.78)$ & $1.05(0.96)^{*}$ \\
\hline
\end{tabular}

Legend: t-test for single sample - zero mean reference; * represents mean statistically different from zero $(p<0.05)$; positive significant values - group commits higher mean number of errors in relation to the means of the reference research; significant negative values-group commits smaller mean number of errors in relation to the means of the reference research. ADHD-Attention Deficit Hyperactivity Disorder; BD - Balanced Dictation.

\section{DISCUSSION}

The results showed that the students in the group with ADHD had a higher error mean than the students in the non-ADHD group, with a statistically significant difference in the total of three of the four alphabetical/ spelling categories analyzed, in the general total of errors on the Balanced Dictation and in the performance compared to the standardized means. This result points in the same direction as earlier studies that showed that students with ADHD have poor spelling performance when compared to their peers without the disorder $6,7,17-23$.

The errors in the Phoneme/Grapheme Conversion category, which are part of the alphabetic stage ${ }^{14}$, are common at the beginning of the literacy process, in which students need to develop metalinguistic functions, such as phonological awareness, to associate the relations between letter and sound. Regarding this relationship, studies show that working memory has the important function of storing verbal material for the development of skills that involve phonological awareness, as is the case of writing ${ }^{29}$. Yet, in a word dictation situation, students may have an overload in their working memory because they need to store what is dictated at the same time as they transcribe. The results of a study ${ }^{7}$ showed that children with spelling difficulties, with ADHD, committed fewer errors in a text-copying task than in a dictation for example. Throughout schooling, with the experience of writing practices and with improved access to the visual and phonological repertoire of the alphabetic principle, students tend to overcome these types of errors. This was not the case for students with ADHD though, who continued to err more than their peers in the three years, as did the results of other samples in which these errors were the most frequent ${ }^{23}$ or were surpassed later than their peers without $A D H D^{6}$ throughout Primary School.

Observing Table 2, we can see that in the Phoneme/Grapheme Conversion category, the highest percentage of errors of students with ADHD was in the subcategory letter or syllable omission. This behavior also occurred in the group without ADHD, however, in this group, there was a significant reduction of errors from one year to the other. In the group with ADHD, there was a significant improvement only when comparing the $3^{\text {rd }}$ year with the $4^{\text {th }}$ and $5^{\text {th }}$ in isolation. It is important to note that, in the $3^{\text {rd }}$ year, students with ADHD committed, on average, three times more errors than students without ADHD. In the $5^{\text {th }}$ year, students without ADHD had almost no errors due to letter or syllable omission, having an average of 0.9 , similar to the average of 0.55 for the $4^{\text {th }}$ grade in that same variable, according to Moojen's research (2011) ${ }^{14}$. Their peers with $A D H D$, however, maintain an average of three errors in grade 5. Attention deficit may be interfering with the omission of letters during the writing of words, being a type of error that usually reflects lack of concentration for writing ${ }^{10}$. As for the total errors in the Phoneme/Grapheme Conversion category, in the three years, the intergroup difference was significant and, as described in Table 6, children with ADHD also presented inferior performance in comparison with the 
standardized means, showing that the disorder influences these results.

In the results of the Simple Contextual Rulescategory, we highlight the errors related to switching $e$ and $i$ and $o$ and $u$. It is noticed that these students still use the spoken language for support. In the schools' regional context, for example, it is common to pronounce "genti" instead of "gente", which can cause the change in writing. It is important to note that students with ADHD in the $4^{\text {th }}$ and $5^{\text {th }}$ year made more mistakes in this subcategory that, according to one study ${ }^{14}$, involves visual memory, as well as metalinguistic strategies of morphological awareness ${ }^{30}$. This error was also frequent in an analysis of different groups' written productions, including students with $A D H D^{20}$.

Furthermore, on the subcategories that involve memory, we highlight the category Language Irregularities. The phoneme /s/ can be represented by nine different graphemes in the Portuguese language. This fact can influence the orthographic errors of Brazilian students because the correct writing of the words depends on mnemonic strategies. In addition to the non-significant results of some subcategories, in the analysis of the total results of this category in Table 5, it is noticed that the students erred more than their peers in the three school years. Also, in none of the subcategories did students with ADHD show any reduction of errors throughout their schooling. In writing, working memory recovers linguistic knowledge and words from long-term memory ${ }^{14,17}$. Such processing could therefore aid in the writing of irregular words. In research investigating the development of different components of working memory in subjects diagnosed with ADHD, however, lower performance results were shown when compared to peers with typical development ${ }^{31-33}$. Thus, those studies can indicate that one of the causes for the low writing performance of subjects with ADHD is the deficit in working memory, but the present study did not analyze the components of students' working memory.

The results of the category Complex Contextual Rulesare in line with Moojen's (2011) ${ }^{14}$ research, which points out that, in the initial years of education, mistakes in relation to accentuation are expected, as the children start to appropriate these rules as education advances, when they begin to have more contact with them. Thus, the differences between conditions are not completely evident in this category. Still, the two groups (with and without ADHD) of the $4^{\text {th }}$ and $5^{\text {th }}$ years showed inferior performance when compared to the standardized means. In this respect, the changes in the Brazilian school curriculum, which extended primary schooling in 2006 to nine years and stipulated that students should be enrolled at six years of age ${ }^{28}$, may have influenced these results. Firstly, because adjustments were made for this study between the reference means from serial education to school years. Even if a correspondence approach was sought between the groups, the curricular changes can influence this result. In the same sense, there are the pedagogical conceptions of the current Brazilian scenario, based on the homologation that extended the literacy cycle to the first three years, $1^{\text {st }}$ to $3^{\text {rd }}$ year ${ }^{34}$, without the possibility of retention in this period. Although the illiterate children were removed from the sample, this factor may have contributed to the lower results students without ADHD evidenced due to variations in the objectives developed for each grade/ year, in each period. Nevertheless, it is risky to reach affirmative conclusions on these possibilities as, in the categories Simple Contextual Rules and Language Irregularities, the $4^{\text {th }}$ year without ADHD performed better than the standardized means. This behavior was also repeated in the variable Language Irregularities in the $5^{\text {th }}$ year. Whatever the reason, the comparison with standardized averages assists in the analysis of the low performance of students with ADHD, which showed a higher average number of errors in all categories.

Limitations of the study, such as the sample size of the ADHD group and the lack of IQ measures of students without ADHD, may have influenced the results. Studies on the evolution of alphabetical/orthographic writing of students with ADHD in the early years of literacy are few, which may be the case due to the late diagnosis of ADHD. It is also worth noting the absence of standardized tests that permit analyzing the writing of children in the literacy process. Further studies are needed to analyze the causes of these writing deficits by analyzing the influence of neurocognitive processes and the symptoms of ADHD or Specific Learning Disorder.

Yet, despite these limitations, the study brings innovations to the areas of education and health. First, by characterizing the types of errors of the alphabetical/spelling stages of the Portuguese language in a sample of Brazilian students with ADHD, considering that, as far as known, most studies with the same objective involve students from other nationalities. Another source of innovation is the use of a non-clinical sample of students with ADHD, which is uncommon in research involving this group of students and was made possible by the diagnostic assessment, within 
the school space, performed by the multidisciplinary team of ProDAH, involving psychiatrists, neuropsychologists, psychopedagogues, academics and research assistants.

These study results entail educational implications that should be highlighted. An attentive look at the orthographic profile of students with ADHD makes it possible to adapt didactic resources and create preventive and corrective interventions to meet this student group's needs. Similarly, it permits raising the school's awareness about the importance of assessing ADHD students' writing according to the spelling rules in the distinguished manner. Finally, further research is necessary in this area, which reveals to be fertile ground for research, and can offer promising results for high-quality inclusive education.

\section{CONCLUSION}

The initial research hypothesis that students with ADHD would perform worse in relation to their peers and to the group of the study by Moojen (2011) ${ }^{14}$ was confirmed. The mean error performance in the total number for each category and in the total number of errors on the Balanced Dictation confirm that the orthographic performance of students with ADHD is low when compared to their peers without ADHD. In addition, the comparison with the standardized means showed greater loss in the group with ADHD. These results evidenced that the condition (with or without ADHD) influenced the students' performance.

\section{ACKNOWLEDGEMENTS}

To the Attention Deficit Hyperactivity Disorder Program for funding part of the research and to the Coordination for the Improvement of Higher Education Personnel (CAPES) for the study grant.

\section{REFERENCES}

1. American Psychiatric Association. DSM-5: manual diagnóstico e estatístico de transtornos mentais. Porto Alegre: Artmed; 2014.

2. Polanczyk GV, de Lima MS, Horta BL, Biederman J, Rohde LAP. The Worldwide Prevalence of ADHD: a systematic review and metaregression analysis. Am. J. Psychiatry. 2007;164(6):942-8.

3. Valiente-Barroso C. Relationship between ADHD Markers and Self-Perceived Stress: influences on academic performance in preadolescents. J. Educ. Develop. Psychology. 2013;3(2):194-203.
4. Dorneles BV, Corso LV, Costa AC, Pisacco NMT, Sperafico YL, Rohde LAP. Impacto do DSM-5 no diagnóstico de transtornos de aprendizagem em crianças e adolescentes com TDAH: um estudo de prevalência. Psicol. Reflex. Crít. 2014;27(4):759-67.

5. Dupaul GJ, Gormley MJ, Laracy SD. School-based interventions for elementary school students with ADHD. Child. Adolesc. Psychiatr. Clin. N Am. 2014;23(4):687-97.

6. Pisacco NT. Expressão escrita de estudantes com Transtorno de Déficit de atenção/hiperatividade: caracterização e intervenção [Tese]. Porto Alegre (RS): Universidade Federal do Rio Grande do Sul, Programa de Pós-Graduação em Educação; 2016.

7. Re AM, Cornoldi C. Spelling errors in text copying by children with dyslexia and ADHD symptoms. J. Learn. Disabil. 2015;48(1)73-82.

8. Cunha VLO, Silva C, Lourencetti MD, Padula NAMR, Capellini SA. Performance of students with attention deficit disorder and hyperactivity in metalinguistic and reading tasks. Rev. CEFAC. 2013;15(1):40-50.

9. Berninger VW, Richards TL. Brain literacy for educators and psychologists. San Diego: Academic Press; 2002.

10. Silva C, Cunha VLO, Capellini SA. Performance cognitive-linguistic and reading of students with Attention Deficit and Hyperactivity Disorder. J. Hum. Growth Dev. 2011;21(3):849-58.

11. Soares M. Alfabetização: a questão dos métodos. 1ed. São Paulo: Ática; 2016.

12. Cagliari LC. A história do alfabeto. $1^{\mathrm{a} e d .}$ São Paulo: Paulistana; 2009.

13. Morais AG. Ortografia: ensinar e aprender. $4^{a} e d$. São Paulo: Editora Ática; 2009.

14. Moojen SM. A escrita ortográfica na escola e na clínica: teoria, avaliação e tratamento. $2^{a}$ ed. São Paulo: Casa do Psicólogo; 2011.

15. Lemle M. Guia teórico do alfabetizador. 17ª ed. São Paulo: Ática; 2010.

16. Capellini SA, Butarelli APKJ, Germano GD. Dificuldades de aprendizagem da escrita em escolares de 1 à à 4 a séries do ensino público. Rev. Educação em Questão. 2010;37(23):146-64.

17. Re AM, Mirandola C, Stefania S, Capodieci A. Spelling errors among children with ADHD symptoms: The role of working memory. Res. Dev. Disabil. 2014;35(9):2199-204.

18. Johnels JA, Kopp S, Gillberg C. Spelling difficulties in school-aged girls with Attention-Deficit/ Hyperactivity disorder: behavioral, psycholinguistic, 
cognitive, and graphomotor correlates. J. Learn. Disabil. 2014;47(5):424-34.

19. Re AM, Pedron M, Cornoldi C. Expressive writing difficulties in children described as exhibiting ADHD symptoms. J. Learn. Disabil. 2007;40(3):244-55.

20. Zorzi JL, Ciasca SM. Análise de erros ortográficos em diferentes problemas de aprendizagem. Rev. CEFAC. 2009;11(3):406-16.

21. Adi-Japha E, Landau YE, Frenkel L, Teicher M, Gross-Tsur V, Shalev RS. ADHD and dysgraphia: underlying mechanisms. Cortex. 2007;43(6):700-9.

22. Silva MLQ. Desempenho em leitura e escrita de alunos com diagnóstico de TDAH [Dissertação]. Curitiba (PR): Universidade Federal do Paraná, Programa de Pós-Graduação em Educação, Mestrado em Educação; 2006.

23. Capellini SA, Fusco $N$, Oliveira AB, Moura R, Lourencetti MD, Antunes LCS et al. Hallazgos de Neuroimagen y desempeño ortográfico de estudiantes con Trastorno por Déficit de Atención con Hiperactividad según la semiología de los errores. Rev. Logop. Foniatr. Audiol. 2011;31(4):219-27.

24. Mattos P, Serra-Pinheiro MA, Rohde LAP, Pinto D. Apresentação de uma versão em português para o uso no Brasil do instrumento MTA-SNAP-IV de avaliação de sintomas do déficit de atenção/ hiperatividade e sintomas de transtorno desafiador e de oposição. Rev. Psiquiatr. Rio Gd. Sul. 2006;28(3):290-7.

25. Angelini A, Alves I, Custódio E, Duarte W, Duarte J. Manual matrizes progressivas coloridas de Raven: escala especial. São Paulo: Centro Editor de Testes e Pesquisas em Psicologia; 1999.

26. Campos F. Teste das Matrizes Progressivas-Escala Geral. Rio de Janeiro: CEPA; 2003.

27. Wechsler D. WISC-IV: Escala de inteligência Wechsler para crianças: manual. $4^{a}$ ed. São Paulo: Casa do Psicólogo; 2013.

28. Brasil. Lei no 11.274. Diário Oficial Da União. Brasília(DF), 7 fev. 2006.

29. Granzotti RBG, Furlan SA, Domenis DR, Fukuda TH. Memória de trabalho fonológica e consciência fonológica em crianças com dificuldade de aprendizagem. Distúrb. Comun. 2013;25(2):241-52.

30. Ygual-Fernández A, Mérida JFC, Cunha VLO, Batista AO, Capellini SA. Avaliação e intervenção da disortografia baseada na semiología dos erros: revisão da literatura. Rev. CEFAC. 2010;12(3):499-504.
31. Gomez R, Gomez RM, Winther J, Vance A. Latent Profile Analysis of Working Memory Performance in a sample of children with ADHD. J. Abnorm. Psychol. 2014;42(8):1367-79.

32. Kofler MJ, Rapport MD, Bolden J, Altro TA. Working memory as a core deficit in ADHD: preliminary findings and implications. Guilford Press. 2008;16(6):8-14.

33. Martinussen S, Tannock S. Working memory impairments in children with attention-deficit hyperactivity disorder with and without comorbid language learning disorders. J. Clin. Exp. Neuropsychol. 2006;28(7):1073-94.

34. Brasil. Resolução CNE/CEB 7/2010. Diário Oficial da União. Brasília(DF) seção 1, p. 34, 15 dez. 2010. 